\title{
7. NEOGENE AND QUATERNARY DINOFLAGELLATE BIOSTRATIGRAPHY OF THE EASTERN EQUATORIAL PACIFIC: DEEP SEA DRILLING PROJECT LEG 851
}

\author{
Ian Jarvis and Bruce A. Tocher, Department of Geology, City of London Polytechnic ${ }^{2}$
}

\begin{abstract}
Samples from DSDP Leg 85 Sites 572-575 in the central equatorial Pacific were analyzed for palynomorph content; only those from Site 572 consistently yielded assemblages of Neogene-Quaternary dinoflagellate cysts. These assemblages are described and compared with coeval material from elsewhere in the world. Several of the 15 species identified are stratigraphically restricted, and comparison with published ranges suggests that they may provide worldwide stratigraphic indices. Nematosphaeropsis labyrinthea (Ostenfeld) Reid and identified species of the genus Impagidinium range from middle Miocene to Quaternary. Palaeocystodinium golzowense Alberti disappears in the middle Miocene and Pyxidiella simplex Harland is restricted to the basal upper Miocene. Operculodinium cf. israelianum Wall and Spiniferites bentorii truncatus (Rossignol) Lentin and Williams are Quaternary species. An increased abundance of dinoflagellate cysts in the uppermost Miocene at Site 572 is associated with the common occurrence of the diatom genera Thalassionema and Thalassiothrix, which are regarded as indicators of upwelling. The higher concentration of dinoflagellate cysts in this interval is related to the location of the site below the equatorial high productivity belt at a time of enhanced local upwelling in the eastern equatorial Pacific.
\end{abstract}

\section{INTRODUCTION}

One of the primary aims of DSDP Leg 85 was to recover undisturbed Neogene-Quaternary sediments in the central equatorial Pacific for detailed biostratigraphic analysis. This was accomplished using the newly developed hydraulic piston corer.

Previous attempts at recovering dinoflagellate cysts from equatorial Pacific sediments have proven unsuccessful (T. Saito, personal communication, 1982). We have proccssed 101 samples from Sites $572-575$ of Leg 85 for biostratigraphic analysis using standard palynological techniques (Neves and Dale, 1963; Doher, 1980). The majority of samples $(92 \%)$ from the central equatorial Pacific (Sites 573-575) were barren. However, all five holes drilled at Site 572, located at the eastern edge of the equatorial sediment bulge (Fig. 1), yielded assemblages of Neogene-Quaternary dinoflagellate cysts (only $7 \%$ barren). Spores and pollen were absent throughout. Biozonal correlations produced by shipboard paleontologists that were based on foraminifers, nannofossils, radiolarians and diatoms have been related (Barron et al., this volume) to the established magnetostratigraphy and chronostratigraphy of the central Pacific. This integrated stratigraphic framework was used to provide age assignments for the palynomorph assemblages recovered. Sample locations at Site 572 are plotted stratigraphically in Figure 2, and the positions of productive samples are listed in Tables 1 and 2.

\footnotetext{
${ }^{1}$ Mayer, L., Theyer, F., et al., Init. Repts. DSDP, 85: Washington (U.S. Govt. Printing Office).

Addresses: Department of Geology, City of London Polytechnic, Walburgh House, Bigland Street, London E1 2NG, UK; (Jarvis, present address) Department of Geology, Kingston Polytechnic, Penrhyn Rd., Kingston-upon-Thames, Surrey KT1 2EE, United Kingdom; (Tocher, present address) Department of Environmental Sciences, Plymouth Polytechnic, Plymouth, Devon PL4 8AA, United Kingdom.
}

\section{BIOSTRATIGRAPHY}

Fifteen species of dinoflagellate cysts have been identified in the present study (Fig. 2). The main species are figured in Plate 1.

\section{Site $\mathbf{5 7 2}$}

Most samples from Site 572 (Fig. 2; Table 1) contain Impagidinium patulum (Wall) Stover and Evitt, I. sphaericum (Wall) Lentin and Williams, and Nematosphaeropsis labyrinthea (Ostenfeld) Reid. Two further species of Impagidinium appear within the succession. I. paradoxum (Wall) Stover and Evitt occurs near the top of the middle Miocene ( $318 \mathrm{~m}$ sub-bottom depth) and ranges into the Pleistocene, whereas I. aculeatum (Wall) Lentin and Williams occurs only in the upper Pliocene and Pleistocene (above $50 \mathrm{~m}$ ). Other genera have more restricted distributions.

Palaeocystodinium golzowense Alberti and Spiniferites pseudofurcatus (Klumpp) Sarjeant occur only in the middle Miocene (423 and $319 \mathrm{~m}$, respectively). Pyxidiella simplex Harland is restricted to the base of the upper Miocene $(262 \mathrm{~m})$, and Operculodinium centrocarpum (Deflandre and Cookson) Wall and Tectatodinium occur in the Miocene and Pliocene. Impagidinium sp. A, Operculodinium cf. israelianum (Rossignol) Wall, Spiniferites bentorii truncatus (Rossignol) Lentin and Williams, and $S$. sp. A occur only in Pleistocene samples (above $5 \mathrm{~m})$.

\section{Other Sites}

Impagidinium patulum, I. paradoxum, and Nematosphaeropsis labyrinthea occur rarely in the upper Miocene and lower Pliocene at Sites 573 and 574 (Table 2). A single specimen of Spiniferites pseudofurcatus was recorded from the lower Oligocene at Site 574. 


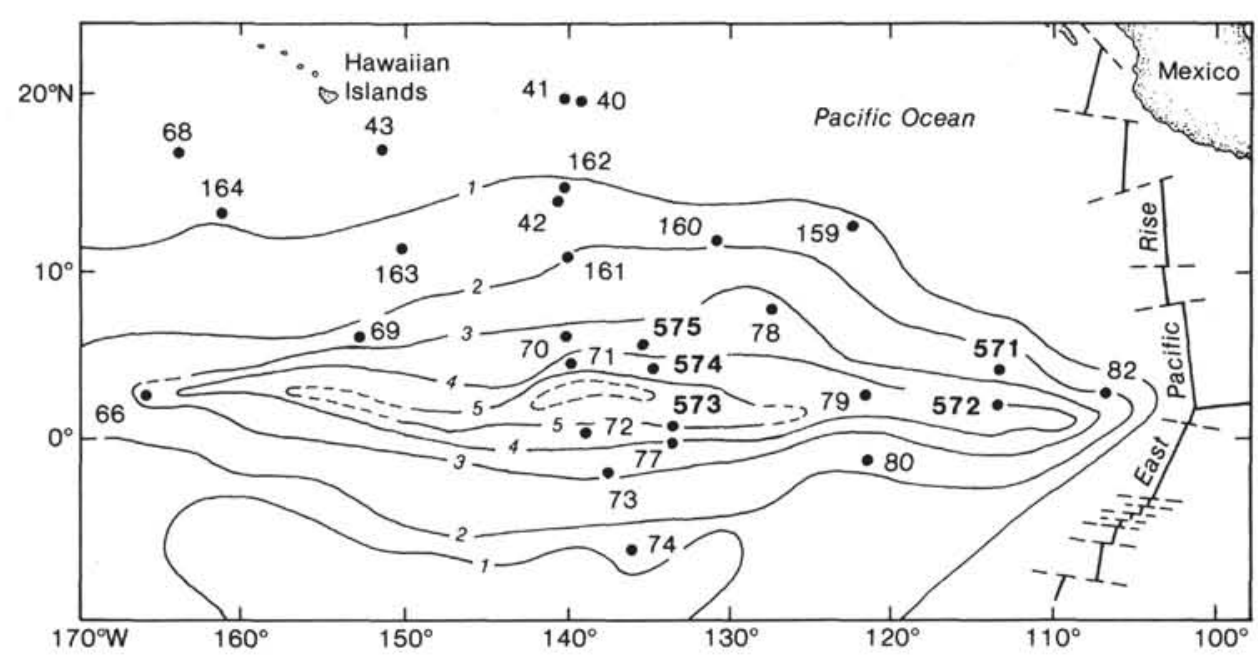

Figure 1. Location map of DSDP Site 572. Positions of other DSDP drill sites in the central Pacific are shown. Contours are in tenths of seconds of two-way traveltime.

\section{DISCUSSION}

The biostratigraphy and paleogeographical range of Neogene and Quaternary dinoflagellate cysts are still poorly known. Pioneering work on Quaternary species by Rossignol $(1962,1964,1969)$ in the eastern Mediterranean, and by Wall $(1967,1970)$ in the Caribbean and western Europe, has been augmented by studies on the Neogene and Quaternary palynology of the Black Sea and the North Atlantic, particularly offshore eastern Canada (see Reid and Harland, 1977; Williams and Bujak, 1977; Harland, 1978, for reviews). We know of no comparable data from the equatorial Pacific, although Neogene and Quaternary dinoflagellates have been recorded in DSDP samples from off the coasts of southern California (Ballog and Malloy, 1981), Mexico (Fournier, 1982), and Peru (Wiseman, 1976).

\section{Dinoflagellate Ranges and Zones}

There is no formal dinoflagellate cyst zonation for the Neogene and Quaternary, although Williams (1975, 1979), Williams and Brideaux (1975), Gradstein and Williams (1976), and Williams and Bujak (1977) have developed an informal scheme based primarily on material from offshore eastern Canada. Other informal schemes have been proposed by Manum (1976) for the Tertiary of the Norwegian-Greenland Sea, by Harland (1978, 1979) for the Neogene and Quaternary of the Bay of Biscay, by Costa and Downie (1979) for the Cenozoic of the Rockall Plateau, and by Piasecki (1980) for the Miocene of Denmark. Our floras correspond most closely to those from the Bay of Biscay (Harland, 1979) but are less diverse.

Palaeocystodinium golzowense was recovered solely from the middle Miocene at Site 572, which supports records (Alberti, 1961; Williams and Bujak, 1977; Williams, 1979; Harland, 1979) suggesting that the species became extinct in the middle Miocene. Pyxidiella simplex occurs only in the basal upper Miocene, confirming data from the Bay of Biscay (Harland, 1979) that indicate that this species is restricted to that stratigraphic level. Operculodinium centrocarpum also only occurs in the Miocene at Site 572, but the species is a common constituent of Quaternary pelagic sediments in many areas (Wall, 1967; Wiseman, 1976; Reid and Harland, 1977) and certainly ranges back to the Eocene (Williams and Bujak, 1977; Williams, 1979). Nematosphaeropsis labyrinthea and three species of Impagidinium (I. paradoxum, I. patulum, and I. sphaericum) range from middle Miocene to Quaternary at Site 572, although $I$. paradoxum appears above the base of the succession. I. aculeatum, on the other hand, occurs only in the upper Pliocene and Quaternary. N. labyrinthea and I. patulum are known to range down into the upper Eocene in the eastern Atlantic (Williams, 1979; Costa and Downie, 1979), but $I$. paradoxum and I. aculeatum first appear in the middle Miocene (Stover and Evitt, 1978; Williams, 1979; Costa and Downie, 1979; Harland, 1978, 1979). We record Spiniferites pseudofurcatus from the middle Miocene at Site 572 and the lower Oligocene at Site 574 (Table 2), but the species is known to extend into the Eocene (Klumpp, 1953; Sarjeant, 1970; Williams and Bujak, 1977; Williams, 1979). O. cf. israelianum and $S$. bentorii truncatus occur only in the youngest sediment at Site 572, conforming with a Pleistocene age for these species (Rossignol, 1962, 1964; Wall, 1967; Wiseman, 1976), although a comparable form of $O$. israelianum is recorded as ranging down into the lower Eocene (Williams and Bujak, 1977; Williams, 1979).

\section{Abundance and Diversity}

The small number of species recorded here from the Neogene and Quaternary of the eastern equatorial $\mathrm{Pa}$ cific is similar to the low diversity displayed by coeval pelagic assemblages from the Atlantic (Williams and $\mathrm{Bu}-$ jak, 1977; Williams, 1979; Harland, 1979) and off the Peruvian coast (Wiseman, 1976). The common occurrence of Impagidinium aculeatum, I. paradoxum, I. patulum, and Nematosphaeropsis labyrinthea supports the widely held view that these are tropical to temperate deep oceanic species (Reid and Harland, 1977; Wall et al., 1977; Harland, 1978, 1979). 


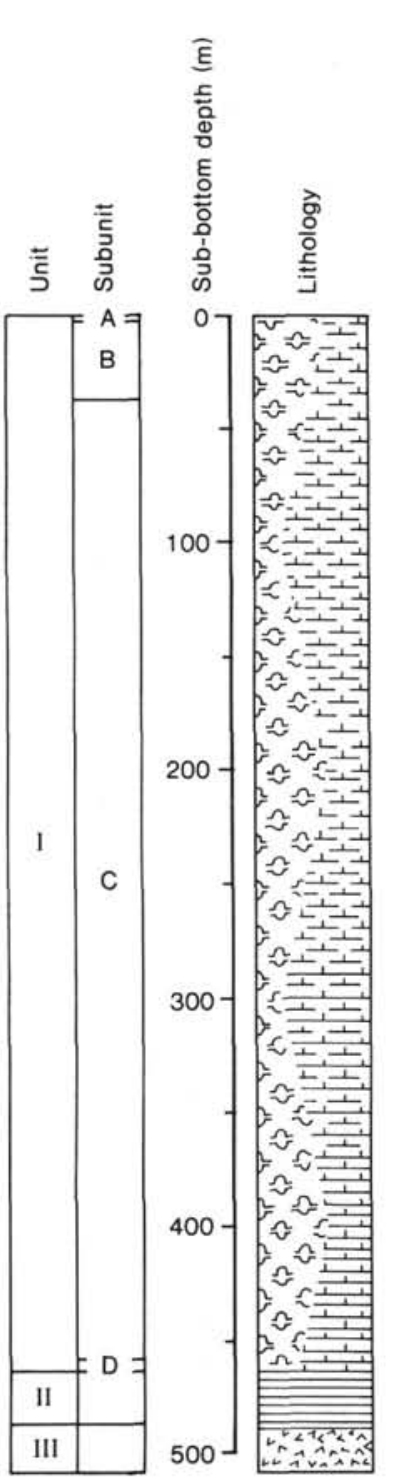

$\approx=$ Diatom radiolarian

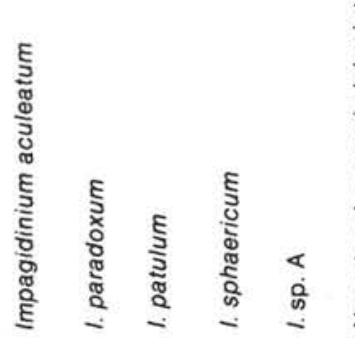

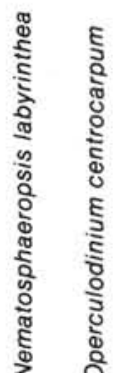

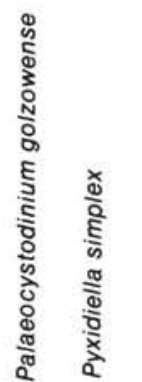

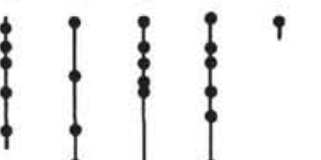

?

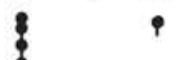

$\boldsymbol{\beta}$

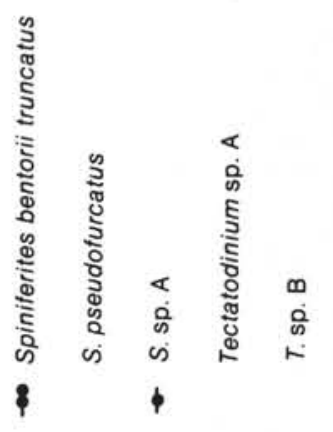

1
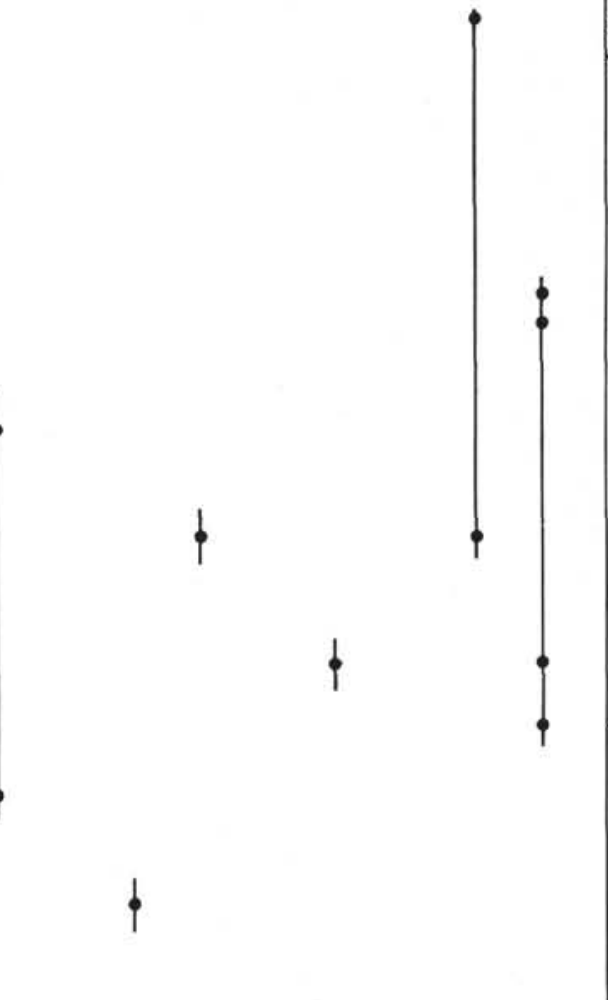

Nannofossil chalk
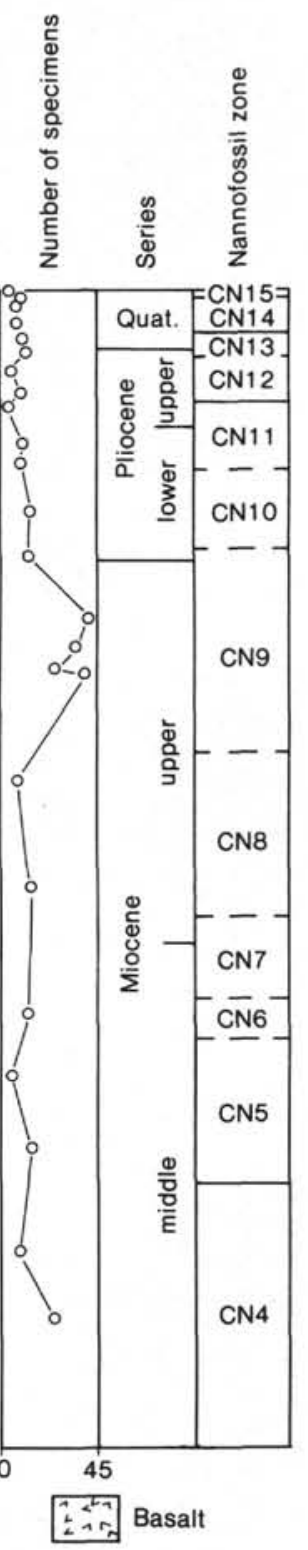

Figure 2. Range chart of dinoflagellate cysts recovered from Site 572. Lithostratigraphic units (left) are those distinguished by Leg 85 sedimentologists. Unit I (0-454.5 m): cyclic siliceous calcareous ooze/chalk; Subunit A, gray brown ooze; Subunit B, varicolored ooze; Subunit C, green varicolored ooze; Subunit D, yellow chalk. Unit II (464.5-?479.5 m): metalliferous chalk. Unit III (479.5-489.0 m): basalt. Chronostratigraphic subdivisions (right) are based on age assignments made by shipboard paleontologists using nannofossils, foraminifers, diatoms, and radiolarians. The nannofossil zonation is based on Pujos (this volume). Dinoflagellate cyst abundance can be gauged from the graph (O-O), which shows the number of specimens recovered from each $20 \mathrm{~g}$ sample of dry sediment.

Uppermost Miocene sediment (140-170 m sub-bottom depth) at Site 572 yielded larger numbers of dinoflagellate cysts than samples from other parts of the succession (Fig. 2), but there is no increase in diversity associated with this acme. The latest Miocene falls within a broader period (late Miocene to early Pliocene, 7.8$4.0 \mathrm{Ma}$ ) characterized at Site 572 by high sedimentation rates and the deposition of sediments with low carbonate contents (Pisias and Prell, this volume). These resulted primarily from high productivity as the site passed through the equator. The deposition of siliceous oozes resulted from the high proportion of siliceous microplankton and the apparently diagenetic dissolution of carbonate, which is indicated by the poor preservation of foraminifers and calcareous nannofossils. Dissolution was probably a consequence of the enhanced preservation of organic matter that resulted from the increased flux of biogenic debris to the seafloor. An increased input of organic matter is supported by the abundance of dinoflagellates. Subsequent oxidation of organic material during early diagenesis caused the dissolution of carbonate. 
Table 1. Samples from Site 572 (27 samples, 2 barren) examined for dinoflagellate cysts.

\begin{tabular}{|c|c|c|c|}
\hline Hole & $\begin{array}{c}\text { Section } \\
\text { (interval in } \mathrm{cm} \text { ) }\end{array}$ & $\begin{array}{l}\text { Sub-bottom } \\
\text { depth (m) }\end{array}$ & Age \\
\hline Hole 572 & $\begin{array}{l}1-1,115-135 \\
1-2,100-120 \\
1-3,100-120\end{array}$ & $\begin{array}{l}1.15-1.35 \\
2.50-2.70 \\
4.00-4.20\end{array}$ & $\begin{array}{l}\text { Quaternary } \\
\text { Quaternary } \\
\text { Quaternary }\end{array}$ \\
\hline Hole $572 A$ & $\begin{array}{l}1-1,0-20 \\
1-4,50-70 \\
2-1,0-20^{\mathrm{a}} \\
3-2,115-135 \\
4-4,95-115 \\
6-3,85-105 \\
9-3,85-105^{\mathrm{a}} \\
13-5,85-105\end{array}$ & $\begin{array}{c}0.00-0.20 \\
5.00-5.20 \\
9.50-9.70 \\
21.65-21.85 \\
34.05-34.25 \\
49.75-49.95 \\
76.15-76.35 \\
116.75-116.95\end{array}$ & $\begin{array}{l}\text { Quaternary } \\
\text { Quaternary } \\
\text { Quaternary } \\
\text { Quaternary } \\
\text { up. Pliocene } \\
\text { up. Pliocene } \\
\text { low. Pliocene } \\
\text { low. Pliocene }\end{array}$ \\
\hline Hole 572B & $2-3,123-143$ & $163.53-163.73$ & up. Miocene \\
\hline Hole $572 \mathrm{C}$ & $\begin{array}{l}2-2,144-150 \\
3-5,144-150 \\
5-5,144-150 \\
7-5,144-150 \\
10-5,144-150 \\
17-3,144-150\end{array}$ & $\begin{array}{c}13.04-13.10 \\
27.14-27.20 \\
46.34-46.40 \\
65.54-65.60 \\
97.34-97.40 \\
144.74-144.80\end{array}$ & $\begin{array}{l}\text { Quaternary } \\
\text { Quaternary } \\
\text { up. Pliocene } \\
\text { low. Pliocene } \\
\text { low. Pliocene } \\
\text { up. Miocene }\end{array}$ \\
\hline Hole 573D & $\begin{array}{l}1-3,144-150 \\
2-5,144-150 \\
7-5,144-150 \\
12-4,144-150 \\
18-4,144-150 \\
21-4,144-150 \\
24-5,144-150 \\
29-4,140-150 \\
32-4,140-150\end{array}$ & $\begin{array}{l}155.44-155.50 \\
167.94-168.00 \\
215.44-215.50 \\
261.44-261.50 \\
318.44-318.50 \\
345.94-346.00 \\
376.94-377.00 \\
422.90-423.00 \\
453.40-453.50\end{array}$ & $\begin{array}{l}\text { up. Miocene } \\
\text { up. Miocene } \\
\text { up. Miocene } \\
\text { up. Miocene } \\
\text { mid. Miocene } \\
\text { mid. Miocene } \\
\text { mid. Miocene } \\
\text { mid. Miocene } \\
\text { mid. Miocene }\end{array}$ \\
\hline
\end{tabular}

Note: Age assignments are based on nannofossil, foraminifer, radiolarian, and diatom determinations made by shipboard paleontologists. No a priori assumptions were made concerning the stratigraphic ranges of dinoflagellate cyst species. Species records are given in Figure 2

a Barren sample.

Table 2. Samples from DSDP Sites 573-575 yielding dinoflagellate cysts.

\begin{tabular}{|c|c|c|c|c|}
\hline Site/Hole & $\begin{array}{c}\text { Section } \\
\text { (interval in } \mathrm{cm} \text { ) }\end{array}$ & $\begin{array}{l}\text { Sub-bottom } \\
\text { depth (m) }\end{array}$ & Age & Species \\
\hline \multicolumn{5}{|c|}{$\begin{array}{l}\text { Site } 573 \\
\text { ( } 28 \text { samples processed, } 24 \text { barren) }\end{array}$} \\
\hline \multirow[t]{2}{*}{ Hole 573} & $\begin{array}{l}9-5,140-150 \\
12-5,140-150\end{array}$ & $\begin{array}{c}74.10-74.20 \\
102.60-102.70\end{array}$ & $\begin{array}{l}\text { low. Pliocene } \\
\text { up. Miocene }\end{array}$ & $\begin{array}{l}\text { 1. paradoxum (1) } \\
\text { I. paradoxum (1) } \\
\text { I. patulum (2) } \\
\text { N. labyrinthea (5) }\end{array}$ \\
\hline & $16-5,140-150$ & $137.70-137.80$ & up. Miocene & $\begin{array}{l}\text { I. paradoxum (4) } \\
\text { N. labyrinthea (1) }\end{array}$ \\
\hline Hole 573A & $6-4,143-150$ & $55.13-55.20$ & low. Pliocene & $\begin{array}{l}\text { 1. paradoxum (1) } \\
\text { I. parulum (2) }\end{array}$ \\
\hline \multicolumn{5}{|c|}{$\begin{array}{l}\text { Site } 574 \\
\quad \text { ( } 29 \text { samples processed, } 27 \text { barren) }\end{array}$} \\
\hline Hole $574 \mathrm{~A}$ & $7-4,144-150$ & $51.84-51.90$ & up. Miocene & N. labyrinthea (1) \\
\hline Hole $574 \mathrm{C}$ & $29-1,135-150$ & $461.85-462.00$ & low. Oligocene & S. pseudofurcatus (1) \\
\hline \multicolumn{5}{|c|}{$\begin{array}{l}\text { Site } 575 \\
\text { (17 samples processed, all barren) }\end{array}$} \\
\hline
\end{tabular}

Note: Age assignments as in Table 1. Samples were identical to those used for pore-water analy. sis; see Stout (this volume) for further details of barren intervals. Number of specimens re. covered are indicated in parentheses after each species.

The concentration of dinoflagellate cysts in Site 572 sediments cannot be related simply to the equatorial location of the site, since other Leg 85 sites yielded few dinoflagellates. Site 572 is unique among the sites examined, however, in having siliceous intervals characterized by sediments composed almost entirely of diatom species (particularly species of Thalassionema and Thalassiothrix), which are regarded as indicators of deep-water productivity and upwelling (Hasle, 1960; Hasle and de Mendiola, 1967; Bukry and Foster, 1973; Sancetta, 1982, 1983). Sediments of this type were deposited at Site 572 (Barron, this volume) during the late Miocene-early Pliocene (7.8-4.0 Ma) when the site crossed the equator and in the middle Miocene (13.0-11.8 Ma), which was an interval of high biogenic silica accumulation throughout the equatorial Pacific (Leinen, 1979). The occurrence of upwelling diatom assemblages has been related to periods of expanded Antarctic glaciation causing increased gyral circulation and increased upwelling throughout the eastern equatorial Pacific (Keller et al., 1982). We suggest, therefore, that Site 572 falls geographically in a broad area favorable to dinoflagellate productivity, but that during the latest Miocene (a period of enhanced upwelling) when the site was located immediately below the equatorial high productivity belt, there was a significant increase in the flux of dinoflagellate cysts to the seafloor.

\section{ACKNOWLEDGMENTS}

This work was completed under the tenure of an Inner London Education Authority postdoctoral research fellowship to I. J. and an ILEA research assistantship to B. A. T. Critical review by the referees greatly improved the original manuscript. Facilities and financial support provided by the ILEA, the Natural Environmental Research Council, and City of London Polytechnic are gratefully acknowledged.

\section{REFERENCES}

Alberti, G., 1961. Zur Kenntnis mesozoischer und alttertiärar Dinoflagellaten und Hystrichosphaerideen von Nord- und Mitteldeutschland sowie einigen anderen Europäischen Gebieten. Palaeontographica, 116A:1-58.

Ballog, R. A., and Malloy, R. E., 1981. Neogene palynology from the southern California continental borderland, Site 467, Deep Sea Drilling Project Leg 63. In Yeats, R. S., Haq, B. U., et al., Init. Repts. DSDP, 63: Washington (U.S. Govt. Printing Office), 565-576.

Bukry, D., and Foster, J. H., 1973. Silicoflagellate and diatom stratigraphy, Leg 16, Deep Sea Drilling Project. In van Andel, T. H., Heath, G. R., et al., Init. Repts. DSDP, 16: Washington (U.S. Govt. Printing Office), 815-872.

Costa, L. I., and Downie, C., 1979. Cenozoic dinocyst stratigraphy of Sites 403 to 406 (Rockall Plateau), IPOD, Leg 48. In Montadert, L., Roberts, D. G., et al., Init. Repts. DSDP, 48: Washington (U.S. Govt. Printing Office), 513-529.

Doher, L. I., 1980. Palynomorph preparation procedures currently used in the paleontology and stratigraphy laboratories, U.S. Geological Survey. U.S. Geol. Surv. Circ. 830.

Fournier, G. R., 1982. Palynostratigraphic analysis of cores from Site 493, Deep Sea Drilling Project Leg 66. In Watkins, J. S., Moore, J. C., et al., Init. Repts. DSDP, 66: Washington (U.S. Govt. Printing Office), 661-670.

Gradstein, F. M., and Williams, G. L., 1976. Biostratigraphy of the Labrador Shelf, part 1. Geol. Surv. Canada Open File, 349:1-39.

Harland, R., 1978. Quaternary and Neogene dinoflagellate cysts. In Thusu, B. (Ed.), Distribution of Biostratigraphically Diagnostic Dinoflagellate Cysts and Miospores from the Northwest European Continental Shelf and Adjacent Area. Continental Shelf Inst. Publ., 100:7-17.

1979. Dinoflagellate biostratigraphy of Neogene and Quaternary sediments at Holes 400/400A in the Bay of Biscay (Deep Sea Drilling Project Leg 48). In Montadert, L., Roberts, D. G., et al., Init. Repts. DSDP, 48: Washington (U.S. Govt. Printing Office), 531-545. 
Hasle, G. R., 1960. Phytoplankton and ciliate species from the tropical Pacific. Skr. Nor. Vidensk. Akad. Math. Naturvis. Kl. (Oslo), 2:1-50.

Hasle, G. R., and de Mendiola, B. R. E., 1967. Fine structure of some Thalassionema and Thalassiothrix species. Phycology, 6:107-125.

Keller, G., Barron, J. A., and Burckle, L. H., 1982. North Pacific late Miocene correlations using microfossils, stable isotopes, percentage $\mathrm{CaCO}_{3}$, and magnetostratigraphy. Mar. Micropaleontol., 7: 327-357.

Klumpp, B., 1953. Beitrag zur Kenntnis der Mikrofossilien des mittleren und oberen Eozän. Palaeontographica, 103A:377-406.

Leinen, M., 1979. Biogenic silica accumulation in the central equatorial Pacific and its implication for Cenozoic paleoceanography. Geol. Soc. Am. Bull., 90:1310-1376.

Manum, S. B., 1976. Dinocysts in Tertiary Norwegian-Greenland Sea sediments (Deep Sea Drilling Project Leg 38), with observations on palynomorphs and palynodebris in relation to environment. In Talwani, M., Udintsev, G., et al., Init. Repts. DSDP, 38: Washington (U.S. Govt. Printing Office), 897-919.

Neves, R., and Dale, B., 1963. A modified filtration system for palynological preparations. Nature (London), 198:775-776.

Piasecki, S., 1980. Dinoflagellate cyst stratigraphy of the Miocene Hodde and Gram Formations, Denmark. Geol. Surv. Denmark Bull., 29:53-76.

Reid, P. C., and Harland, R., 1977. Studies of Quaternary dinoflagellate cysts from the North Atlantic. Am. Assoc. Strat. Palynol. Contrib., 5A:147-165.

Rossignol, M., 1962. Analyse pollinique de sédiments marins Quaternaires en Israël II: sédiments Pleistocènes. Pollen Spores, 4:121-148.

1964. Hystrichosphères du Quaternaire en Méditerranée orientale, dans les sédiments Pleistocènes et les boues marines actuelles. Revue Micropaléont., 7:83-99.

, 1969. Sédimentation palynologique dans le domaine marin Quaternaire de Palestine: étude de paléoenvironnement: notes et mémoires sur le Moyen-Orient. Mus. Nat. Hist. Natur. Paris, 10: $1-272$.

Sancetta, C. A., 1982. Diatom biostratigraphy and paleoceanography, Deep Sea Drilling Project Leg 68. In Press, W. L., Gardner, J. V., et al., Init. Repts. DSDP, 68: Washington (U.S. Govt. Printing Office), 301-309.
1983. Biostratigraphic and paleoceanographic events in the eastern equatorial Pacific: results of Deep Sea Drilling Project Leg 69. In Cann, J. R., Langseth, M. G., Honnorez, J., Von Herzen, R. P., White, S. M., et al., Init. Repts. DSDP, 69: Washington (U.S. Govt. Printing Office), 311-319.

Sarjeant, W. A. S., 1970. The genus Spiniferites Mantell, 1850 (Dinophyceae). Grana, 10:74-78.

Stover, L. E., and Evitt, W. R., 1978. Analyses of pre-Pleistocene organic-walled dinoflagellates. Stanford Univ. Publ. Geol. Sci., 15: 1-300.

Wall, D., 1967. Fossil microplankton in deep-sea cores from the Caribbean Sea. Palaeontology, 10:95-123. 1970. Quaternary dinoflagellate micropaleontology: 19591969. Proc. North Am. Paleont. Convention, G:844-866.

Wall, D., Dale, B., Lohmann, G. P., and Smith, W. K., 1977. The environmental and climatic distribution of dinoflagellate cysts in modern marine sediments from regions in the North and South Atlantic Oceans and adjacent seas. Mar. Micropalaeontol., 2:121-200.

Williams, G. L., 1975. Dinoflagellate and spore stratigraphy of the Mesozoic-Cenozoic, offshore eastern Canada. Geol. Surv. Canada Paper, 74-30, 2:107-161. 1979. Palynological biostratigraphy, Deep Sea Drilling Project Sites 367 and 370. In Supko, P. R., Perch-Nielsen, K., et al., Init. Repts. DSDP, Suppl. to Vols. 38, 39, 40, and 41: Washington (U.S. Govt. Printing Office), 783-815.

Williams, G. L., and Brideaux, W. W., 1975. Palynological analysis of late Mesozoic-Cenozoic rocks of the Grand Banks off Newfoundland. Geol. Surv. Canada Bull., 263:1-162.

Williams, G. L., and Bujak, J. P., 1977. Cenozoic palynostratigraphy of offshore eastern Canada. Am. Assoc. Strat. Palynol. Contrib., 5A:14-47.

Wiseman, J. F., 1976. Palynological investigation of samples from Holes 319, 320, 320A and Site 321 of DSDP Leg 34. In Yeats, R. S., Hart, S. R., et al., Init. Repts. DSDP, 34: Washington (U.S. Govt. Printing Office), 741-742.

Date of Initial Receipt: 3 October 1983 Date of Acceptance: 26 April 1984 


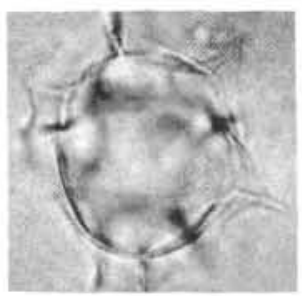

1

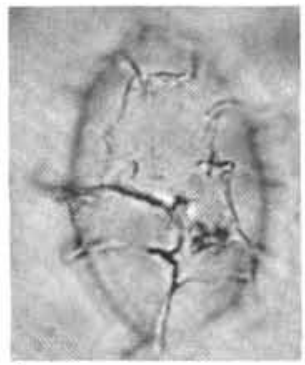

5

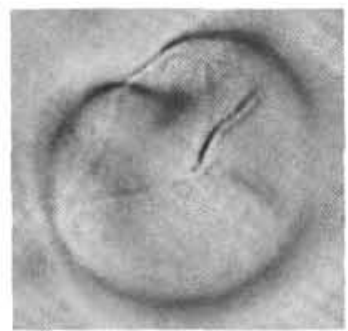

12

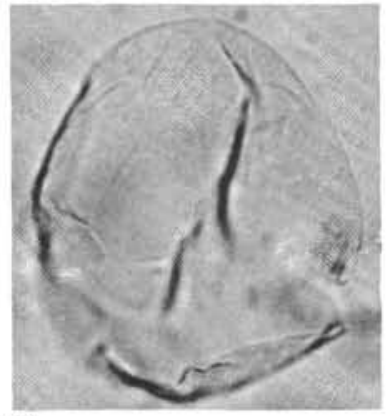

14

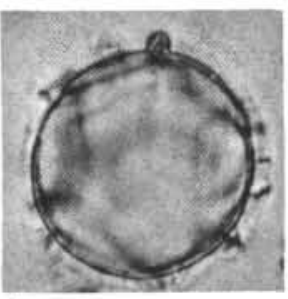

2

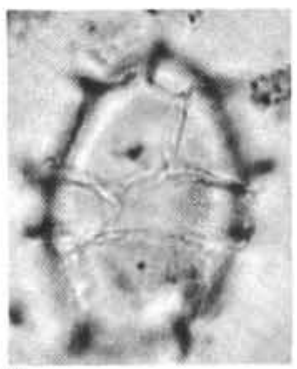

6

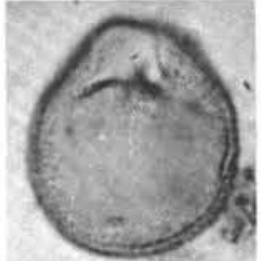

13

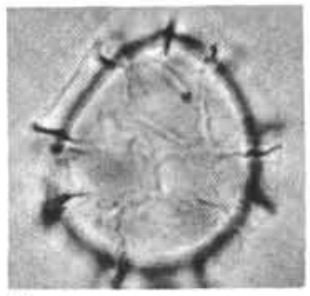

3

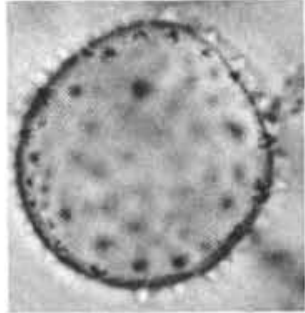

8

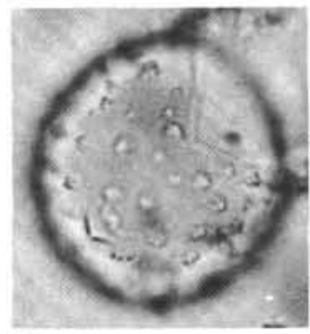

9

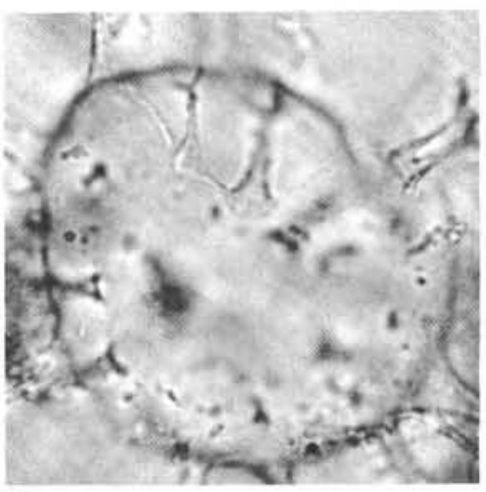

15

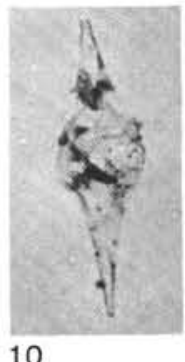

10

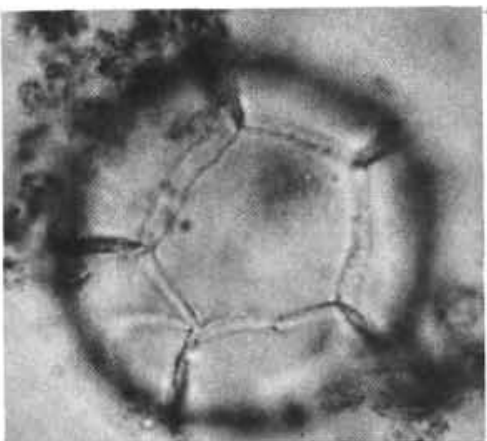

4

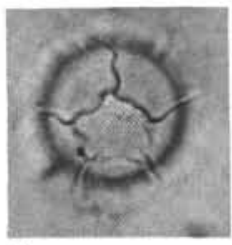

7

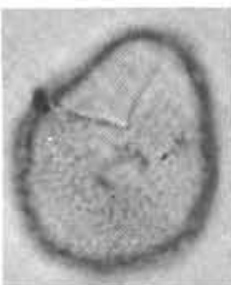

11

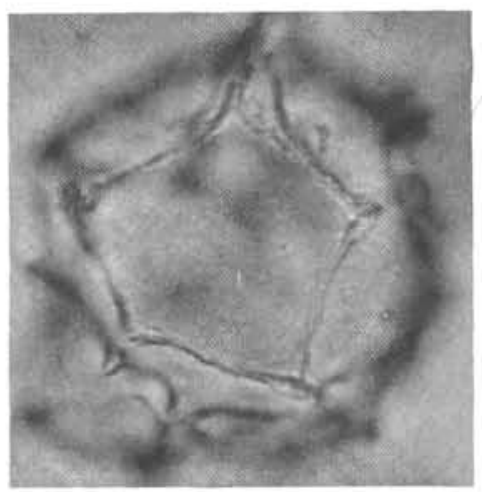

16

Plate 1. Dinoflagellate cysts from DSDP Site 572. (All figures magnified $\times 1000$ unless otherwise indicated.) 1. Impagidinium aculeatum (Wall) Lentin and Williams, Sample 572A-3-2, 115-135 cm, 21.65-21.85 m sub-bottom depth. 2-3. I. sphaericum (Wall) Lentin and Williams, Sample 572C-2-2, 144-150 cm, 13.04-13.10 m. 4. I. patulum (Wall) Stover and Evitt, Sample 572-1-3, 100-120 cm, 4.00-4.20 m. 5-6. I. paradoxum (Wall) Stover and Evitt, Sample 572C-3-5, 144-150 cm, 27.14-27.10 m. 7. I. sp. A, Sample 572-1-1, 115-135 cm, 1.15-1.35 m. 8-9. Operculodinium cf. israelianum (Rossignol) Wall, Sample $572-1-1,115-135 \mathrm{~cm}, 1.15-1.35 \mathrm{~m} . \quad 10$. Palaeocystodinium golzowense Alberti, $\times 400$, Sample 572D-29-4, 140-150 cm, 422.90-423,00 m. 11. Tectatodinium sp. B, Sample 572D-12-4, 144-150 cm, 261.44-261.50 m. 12. T. sp. A, Sample 572A-4-4, 95-115 cm, 34.05-34.25 m. 13. Pyxidiella simplex Harland, Sample 572D-12-4, 144-150 cm, 261.44-261.50 m. 14. Cyst (?Protoperidinium) sp. A, Sample $572 \mathrm{C}-5-5,144-150 \mathrm{~cm}, 46.34-46.40 \mathrm{~m}$. 15. Spiniferites sp. A, Sample 572A-1-4, 50-70 cm, 5.00-5.20 m. 16. S. bentorii truncatus (Rossignol) Wall and Dale, Sample $572 \mathrm{~A}-1-4,50-70 \mathrm{~cm}, 5.00-5.20 \mathrm{~m}$. 